\title{
Engineering Bacterial Competitiveness and Persistence in the Phytosphere
}

\author{
Michael A. Savka, ${ }^{1}$ Yves Dessaux, ${ }^{2}$ Phil Oger, ${ }^{2,3}$ and Silvia Rossbach ${ }^{4}$ \\ ${ }^{1}$ Department of Biological Sciences, Rochester Institute of Technology, Rochester, NY 14623, U.S.A.; ${ }^{2}$ Institut des \\ Sciences du Végétal, Centre National de la Recherche Scientifique, Bâtiment 23, F-91198, Gif-sur-Yvette, France; \\ ${ }^{3}$ Laboratoire de Sciences de la Terre, Ecole Normale Supérieure, Lyon, France; and ${ }^{4}$ Department of Biological Sciences, \\ Western Michigan University, Kalamazoo, MI 49008, U.S.A.
}

Submitted 5 February 2002. Accepted 17 May 2002.

Several tactics exist to improve the survival of an introduced microorganism of interest in the plant environment. One, derived from studies on the Agrobacterium-plant interaction and the role of opines in this interaction, proposes to promote growth of the inoculant in the plant environment via the establishment of a bias in the rhizosphere. It is supported by the occurrence of natural biases, such as those generated by opine-like molecules, by calestegins, or by mimosine. Opine-mediated biases have allowed several investigators to favor the growth of opine-degrading bacteria or communities under sterile or axenic environments or in microcosms mimicking near field conditions. Another way to favor a given microbe consists in impeding growth of competing microorganisms. Experiments performed using detergent or bacteriostatic agents as amendments under field or near field conditions yielded promising results. Research perspectives for engineering plant-microbe interactions also include specific engineering of predation and strategies designed to interfere with some of the signals perceived by the microbes, provided these signals control the expression of functions central to microbial fitness. In this respect, quorum-sensing signal molecules, such as $N$ acyl-homoserine lactones, may be valuable targets for the development of biocontrol agents and procedures.

Additional keywords: biased rhizosphere, rhizopine.

Within the past years, the modification of bacterial populations in agricultural production systems has received much attention (Curl and Truelove 1986; Rovira 1991). Most of the reported work has dealt with the isolation of plant growth promoting rhizobacteria (PGPR) (Kloepper and Schroth 1978), including biocontrol agents, and with the elucidation of the molecular mechanisms conferring plant growth promotion or biocontrol properties upon these organisms (Adams 1990; Bloemberg and Lugtenberg 2001; Cook et al. 1995; Van Loon et al. 1998). In spite of our good understanding of these mechanisms (O'Sullivan and O'Gara 1992; Schippers et al. 1987; Van Loon et al. 1998), several PGPR or biocontrol agents that appeared promising when examined in vitro or under microcosm test conditions have failed to exhibit these traits when associated with the cultivated plants (Cullen and Andrews 1984; Schippers et al.

Corresponding author: Yves Dessaux; Telephone: +33 16982 3690; Fax: +33 16982 3695; E-mail: dessaux@isv.cnrs-gif.fr.
1987), possibly because they are of limited fitness under field conditions. Improving the competitiveness of a PGPR in the plant environment is likely to be a key step in improving its growth promotion or biocontrol ability (Bowen 1991; O'Connell et al. 1996). To do so, it is essential to understand the basis of microbial adaptation to the plant environment.

In the rhizosphere, microbes compete via the production of, and resistance to antibacterial or antifungal compounds that originate both from the plant root system and from other soil organisms (Curl and Truelove 1986; Grayer and Kokubun 2001; Mazzola et al., 1992; Stutz et al. 1986; Thomashow and Weller 1988). Microbes also compete for the utilization of the abundant, organic compounds released by the plant upon growth (Rovira 1965a, 1965b) and for mineral elements such as iron (Kloepper et al. 1978; Lemanceau et al. 1992; Loper and Buyer 1991; Mirleau et al. 2000), i.e., they compete for resources. Abiotic factors-such as temperature, osmotic pressure, UV light, and $\mathrm{pH}$ - and the relevant variations of these factors also play a role in the selection and activity of microbes in soils or at the plant surface (Arrage et al. 1993; Kulkarni and Nautiyal 2000; Naseby and Lynch 1999). From the above, it appears that the microorganisms living at the plant surface are well adapted to the biological and physico-chemical constraints of the environment (Curl and Truelove 1986; Parke 1991). Hence, they are poorly accessible to displacement by the introduced microbe.

The biased rhizosphere hypothesis.

Several possibilities exist to improve the competitiveness of an introduced microorganism of interest in the plant environment (Bowen 1991; Lam and Gaffney 1993; O'Connell et al. 1996; Parke 1991). One may promote its multiplication in the plant environment, impede growth of competing microorganisms, or interfere with some of the signals perceived by the microbes, provided these signals control (at least in part) the expression of functions central to microbial fitness. Because this environment is a triple interface (bacteria, plant, and soil), it is theoretically possible to modify one, two, or three of these parameters to improve microbial colonization. However, experiments involving modification of atmospheric or soil factors as means to engineer leaf and root microbial components are seldom reported.

Metabolic resources are known to be key determinants of microbial colonization of plants (Curl and Truelove 1986; Rovira $1965 \mathrm{a} ; 1965 \mathrm{~b})$. In the rhizosphere, for instance, microbial growth is stimulated in part by carbon and nitrogen compounds 
released by the plant, a phenomenon termed rhizodeposition (Whipps and Lynch 1985). This stimulation is selective: it concerns only those microbes that can "adapt to specific root excretions," as remarkably predicted by L. Hiltner in 1904 (Curl and Truelove 1986). Because the composition of root exudates varies, the microbial communities colonizing the root system of plants differ from one plant genus to another, from one plant species to another, from one cultivar to another, and from one growth stage to another (Curl and Truelove 1986; Grayston et al. 1998; Lemanceau et al. 1995; Miethling et al. 2000; Picard et al. 2000; Rengel et al. 1998; Siciliano et al. 1998; Westover et al. 1997). Therefore, it appears that engineering beneficial plant-microbe associations calls for "broad host range" procedures, i.e., procedures that can be used with many different plants.

One of the broad host range procedures that may be used to selectively promote the multiplication of a microbe or interest in the plant environment derives from a generic concept termed "rhizosphere engineering" (O'Connell et al. 1996), or "biased rhizosphere" (Rossbach et al. 1994a, 1994b, 1994c), originating from studies of the well-known Agrobacterium tumefaciens-plant interaction. The pathogenic agrobacteria genetically engineer the host plant (Zupan et al. 2000) to synthesize carbon and nitrogen-containing molecules (the opines) that specifically provide themselves with an ecological niche, favoring its growth and the dissemination of pathogenicity (Dessaux et al. 1998). The biased rhizosphere hypothesis proposes to mimic this natural interaction and to favor the growth of a microbe of interest in a plant environment by engineering the plants to synthesize one or more novel compounds and the bacterial partner (such as a PGPR) to degrade these novel compounds. As described below, early work has involved an opine-based bias. Indeed, opine production is very abundant, up to $7 \%$ of the dry weight of the plant tissues (Tate et al. 1982), making them valuable nutrient resources. Because opine-utilizing bacteria in soil are rare (Nautiyal et al. 1991; Tremblay et al. 1987) and the genes involved in opine synthesis and degradation are available and expressed in the appropriate eukaryotic and prokaryotic backgrounds, opine-based strategies for the selective promotion of the growth of microbes have been proposed and developed (Dessaux et al. 1987; Guyon et al. 1993; Lam et al. 1991; Lam and Gaffney 1993; Oger et al. 1997; Savka and Farrand 1992, 1997; Wilson et al. 1995).

\section{Natural instances of biased rhizosphere.}

If the above biased rhizosphere hypothesis is valid, it is reasonable to speculate that other natural examples of "metabolic colonization" can be evidenced in addition to the Agrobacterium spp. opine system. Indeed, at least two other instances of metabolic colonization are known. The first one involves the alkaloid compounds calystegins (Molyneux et al. 1993), produced by various plant and tree species such as hedge bindweed (Calystegia sepium, hence the name), field bindweed or wild morning glory (Convolvulus arvensis), scopolia (Scopolia japonica), and white mulberry (Morus alba) (Asano et al. 1994, 1996; Tepfer et al. 1988). None of these plant species initiates a symbiotic association for nitrogen fixation with $R h i$ zobium sp. strains. Nevertheless, bacterial isolates degrading calystegins as a sole carbon and nitrogen source have been found associated with the root system of Calystegium sp., mainly Sinorhizobium meliloti Rm41 (Tepfer et al. 1988). In this way, calystegin production may, in part, contribute to the selection of a well-adapted soil microflora by the plants mentioned above, possibly by inhibiting microbial functions (such as glycosidases and trehalase) (Asano et al. 1994, 1996) or by providing the calystegin-resistant bacteria with a dedicated carbon and nitrogen source. It is interesting to note that calyste- gins are generally abundant in the roots of the plants but are found only in limited amounts in aerial plant parts (Tepfer et al. 1988).

Another example of biased rhizosphere may be found among members of the Rhizobiaceae family. Several Rhizobium strains and related legume-associated species have evolved the ability to synthesize simple carbon compounds, the function of which resembles that of opines associated to the Agrobacterium-plant interaction. For this reason, they have been termed opine-like molecules (Dessaux et al. 1998). One of these molecules, rhizopine, is the inositol derivative L-3-O-methyl-scylloinosamine (3-O-MSI) (Murphy et al. 1987); it was originally detected in some alfalfa nodules (Tempé et al. 1982). There is a major difference between the agrobacterial opines and the rhizobial rhizopine. Whereas the agrobacterial opine synthesis genes are transferred to the plant nuclear chromosome and expressed during the parasitic interactions between Agrobacterium spp. and higher plants (Zupan et al. 2000; Savka and Binns 2000), the rhizobial rhizopine synthesis genes are expressed in the bacterial cell during endosymbiosis in the plant nodules (Dessaux et al. 1998). However, it is interesting to note that corresponding to the location of the opine synthesis and catabolism genes on the agrobacterial Ti-plasmid, the rhizobial rhizopine genes are located on the rhizobial sym-plasmid in the vicinity of other genes essential for nitrogen fixation (Murphy et al. 1987). This suggests that presence of 3-O-MSI in the environment may constitute a selective pressure favoring the growth of the Rhizobium strains harboring the sym-plasmid, hence genes essential for nitrogen fixation. Mutants of a $S$. meliloti strain affected in rhizopine synthesis or rhizopine catabolism were inoculated onto alfalfa host plants in competition experiments with the wild-type strain. While no apparent advantage resulted from the ability to synthesize rhizopine, the ability to catabolize rhizopine indeed provided a growth advantage to the rhizopine-degrading wild-type strain in comparison to the non-rhizopine-utilizing mutant strain (Gordon et al. 1996).

A last example of biased rhizosphere also involved Rhizobium strains, more precisely, those inhabiting the nodules that develop on Leucaena and Mimosa sp. These tree-legumes, as well as their nodules, contain a toxic compound termed mimosine (Hammond 1995). Interestingly, Rhizobium cells colonizing the nodules have acquired the ability to fully degrade mimosine, using it as a sole carbon and nitrogen source (Soedarjo and Borthakur 1996, 1998). Mimosine, therefore, appears to be a valuable nutrient source and a selective agent for the ad hoc nodule-inciting Rhizobium cells. Indeed, growth of Tn3 insertion mutant strains that have lost the ability to catabolize mimosine is impaired in medium containing 3-hydroxy-4pyridone, a toxic metabolite resulting from the partial degradation of mimosine (Fox and Borthakur 2001). This compound also exhibits antimitotic activity on eukaryotic animal cells. As a consequence, ruminants feeding on Leucanea sp. may experience cataracts, reduced appetite, goiter, and reduced weight gain (Holmes et al. 1981). These toxic effects have not been noticed in regions where Leucanea sp. originated, because ruminants there have evolved an intestinal microflora degrading mimosine. This microflora can be used as a cattle-food complement to "inoculate" the digestive tracts of sensitive ruminants, conferring a complete resistance to mimosine upon the treated animals (Jones and Megarrity 1986, Hammond et al. 1989; Allison et al. 1990). The latter example is of great interest, because it demonstrates that a trophic relationship can likely be established with any type of plant and in any type of soil, as the mimosine-based bias operates in different, unrelated complex environments ranging from the soil to the intestinal tracts of ruminants. 
Testing the biased rhizosphere hypothesis by amendment of agricultural soils.

Elegant experiments based on the repeated selection of microorganisms using various exogenous compounds brought to the plant environment as soil amendments have been reported. The first ones involved a molecule playing a dual role, both as an antibacterial agent and as a putative carbon source. One of these selective molecules was sodium salicylate. Under fieldlike conditions, Colbert and associates (1993a, 1993b, 1993c) compared the populations and metabolic activities of two Pseudomonas putida strains, namely PpG7 and PpG7(pNAH7), the latter being able to degrade salicylate in soils amended or not amended with this molecule. In nonsterile bulk soils, population densities of the introduced microbe-degrading salicylate increased up to approximately 100 -fold within two weeks of the initial application of salicylate, as compared with the densities found in nonamended bulk soil. Meanwhile, the population of the salicylate-degrading $P$. putida strain increased up to approximately 20-fold at the root surface of plants installed in this soil (Colbert et al. 1993b). Another series of experiments involved a biocontrol $P$. putida strain, an antagonist and a derivative of Pythium ultimum, that harbored plasmid pNAH7, conferring salicylate resistance and degradation. Metabolic activity of the salycilate-degrading bacteria was enhanced in the soil amended with salicylate, as judged by respirometry. Meanwhile, the salicylate-degrading strain outgrew the parent strain by two orders of magnitude, depending on the concentration of salicylate in the soil (Colbert et al. 1993c). A low concentration of salicylate did not inhibit the growth of the degrading bacteria but inhibited that of the nondegrading one, while elevated concentrations inhibited both types of strains. The authors did not observe any growth stimulation of the salicylate resistant strains on germinating seeds of sugar beet in the presence of low concentration of salicylate; however, they reported that population densities of the salicylate-degrading $P$. putida strain decreased significantly less in soil amended with salicylate than in nonamended soil (Colbert et al. 1993c).

Other attempts similar to those mentioned above have been reported using detergent molecules that were both antibacterial agents and putative carbon sources (Howe and Ward 1976; Lajoie et al. 1992). In field experiments, growth of Pseudomonas strains resistant to the detergent "Ipegal" was efficiently stimulated by detergent amendment (Devliegher et al. 1995). Under these conditions, the cell density of the detergent-resistant Pseudomonas strains increased by three orders of magnitude in two days, while the control performed in the absence of amendment or involving an amendment with a nonselective substrate did not result in any growth stimulation of the detergent-habituated strain. In another series of experiments, the survival characteristics of two PGPR, detergent-habituated Pseudomonas strains was monitored in bulk soil and in the rhizosphere of various plants. In bulk soil, the survival of detergent-adapted strains was 10 to 100 times higher in the presence of the detergents. In the rhizosphere, i.e., when the PGPR encounter a high density of competing micro-organisms, the results depended on the detergent used, the Pseudomonas strain, the plants, and the experimental design (Devliegher et al. 1995). This last result supports the view that community ecology may be a "required knowledge" for engineering the rhizosphere (O’Connell et al. 1996).

\section{Plant-associated microbial populations engineering via management of metabolic resources.}

As stated above, engineering beneficial plant-microbe associations calls for broad host range procedures, i.e., procedures that can be used whatever the plants requiring protection and whatever the soil substrate. In this respect, the interest of the biased rhizosphere strategy was recently strengthened by the direct demonstration that the opine-induced bias is independent of the type of opine, the origin of soil, and the genus of the transgenic plants producing the opines (Mansouri et al. 2002), making it a potentially very versatile system to engineer resources in the plant environment.

\section{Opine-induced bias in the rhizosphere.}

Here, the bias introduced in the rhizosphere consists in engineering a plant to produce one or more compounds not usually found in the exudates, i.e., opines, and in engineering the inoculated bacteria to degrade these compounds, thus establishing a trophic link between the two partners of the interaction (Dessaux et al. 1987). Opine-producing plants can be obtained (Savka and Binns 2000) for opine biosynthetic genes, and proteins have evolved to be expressed in such a genetic background. Interestingly, opines can be translocated in the plant and made available as a nutritional resource for microbes in the rhizosphere, phyllosphere, or other regions of the plant (Savka et al. 1996). Opine production does not appear to be drastically affected by the plant species and is usually high. The mannityl opines (mannopine, agropine, mannopinic, and agropinic acids) were estimated to accumulate to between 20 and $30 \mu \mathrm{g}$ per $\mathrm{g}$ of tissue dry weight in tissues of transgenic Lotus sp. (Guyon et al. 1993), whereas in transgenic Nicotiana, these opines were estimated to accumulate to between 100 and $150 \mu \mathrm{g}$ per $\mathrm{g}$ of dry weight of root, stem, and leaf tissues (Savka and Farrand 1992). In opine-accumulating tobacco plants, the mannityl opines accumulated in the hydroponic growth medium to 540 $\mu \mathrm{g}$ per mg of dry weight of root tissue after 60 days of growth and were present in leaf rinses indicating the presence of these opines in the rhizosphere and phyllosphere (Savka 1993; Savka and Farrand 1992).

The opine-based strategy for engineering plant-microbe interactions was first assessed in vitro. Under hydroponic conditions, with Lotus corniculatus plants producing or not producing the four mannityl opines and with agrobacteria degrading or not degrading these opines, Guyon and associates (1993) demonstrated that the growth of the opine-degrading agrobacteria was specifically stimulated at the root system of opineproducing plants. Interestingly, the opine concept-which has remained a predictive theory for years-received a direct demonstration from the simple experiment presented above and from similar early work involving plants producing opines, opine-utilizing pseudomonads, and mutants with Tn5-inactivated opine catabolizing genes (Lam and Gaffney 1993; Lam et al. 1991).

In a second series of experiments designed similarly to those of the first series, the Agrobacterium strains were replaced by Pseudomonas strains that degraded or did not degrade the opines. No significant growth stimulation of opine-degrading Pseudomonas strains in the rhizosphere of opine-producing plants was observed (P. Guyon, unpublished data), most likely because the cosmids conferring opine catabolism upon pseudomonads (Dessaux et al. 1987) were not stable in this background. These data suggest that efficient growth stimulation of opine-utilizing bacteria requires catabolic genes that should be located either on a very stable replicon or integrated within one or more bacterial chromosomes. This observation was exploited by Savka and Farrand (1997), who constructed related lines of Pseudomonas fluorescens strains degrading or not degrading one of the mannityl opines (agropine) with chromosomally located catabolic genes. Seeds of tobacco lines producing or not producing this opine were inoculated with each bacterium alone and with a mixture of the two bacteria and allowed to germinate in a microcosm consisting of sterile soil. 
When inoculated alone, both bacteria colonized the roots of the normal and opine-producing plant with equal kinetics and obtained similar population levels, indicating that the carryingcapacity (a concept which describes "how many" organisms can grow in a given environment with respect to the available resources and existing predation) was not altered by directing carbon and nitrogen to opine production or by engineering bacteria to utilize a dedicated carbon and nitrogen source. In coinoculations in the rhizosphere of only the opine-producing plants, the opine-catabolizing strain out-competed the noncatabolizing strain, with population densities two to three times higher than those of the noncatabolizing strain. This competitive advantage was most pronounced in populations closely associated with the roots (Farrand et al. 1994a, 1994b; Savka and Farrand 1992, 1997). This work demonstrates that agropine exuded by the plants into the rhizosphere can influence the structure of the rhizobacterial populations.

\section{Nodule-specific compounds as growth enhancers.}

An alternative to using Agrobacterium-induced opines to construct a biased rhizosphere may involve Rhizobium-induced rhizopines and may be based on the metabolism of 3-O-MSI (Rossbach et al. 1994a, 1994b, 1995a). To evaluate the effectiveness of such a rhizopine-based system, experiments involving alfalfa plants and $S$. meliloti were performed. Alfalfa plants were inoculated with various rhizopine-synthesizing rhizobia, which degraded rhizopine (Moc+) or did not degrade (Moc-), in a 1:1 ratio. At one, two, and three months after inoculation, the portion of the Moc-strains inhabiting the nodules were 24, 8, and 10\%, respectively (Rossbach et al. 1995a). Thus, the rhizopine-utilizing wild type was clearly favored in its ability to successfully inhabit nodules, as also reported by Gordon and associates (1996). Using the same model system, a recent report indicates a stimulation of the population of rhizopine-degrading strains over a four-year period (Heinrich et al. 1999). The above findings speak for a selective advantage of rhizopine-utilizing over nonutilizing bacteria. This suggests that rhizopine-based strategies may be of interest, provided genes involved in rhizopine biosynthesis and degradation may be eventually expressed in plants and PGPR, respectively.

Genes responsible for rhizopine degradation and synthesis had been identified earlier (Murphy et al. 1987). The rhizopine catabolism genes have been cloned and their DNA sequence has been determined (Rossbach 1994a). Four moc genes were essential for 3-O-MSI catabolism in S. meliloti: $\operatorname{mocA}$, mocB, $\operatorname{moc} C$, and mocR. A minimal moc-cassette was constructed (Rossbach et al. 1994b) and conferred the ability to degrade rhizopine upon other rhizobial strains of agronomical interest (Rossbach et al. 1994b). However, these genes were not sufficient to confer the ability to degrade rhizopine upon a variety of other bacteria tested, including P. fluorescens, Azospirillum brasilense, and Enterobacter aerogenes (S. Rossbach, unpublished data).

Rhizopine synthesis depends on three genes arranged in an operon: mosABC (Murphy et al. 1993). Though gene sequences are known, the functions of the encoded proteins are not fully understood. To achieve expression of the mos genes in plant cells, the $\operatorname{mos} A, \operatorname{mos} B$, and $\operatorname{mos} C$ genes have been cloned behind three different plant specific promoters (CaMV35S, mas1, and mas2), and Arabidopsis plants were transformed with these constructs containing the plant expressible $\operatorname{mos} A, \operatorname{mos} B$, and mosC genes (McSpadden-Gardener 1998). Although all three mos genes were shown to be present and to be expressed in the transgenic plants, no transgenic plant was found to synthesize rhizopine (McSpadden-Gardener 1998).

One of the values of rhizopine as a novel resource lies in the relative low abundance of 3-O-MSI-degrading microorganisms compared with opine-degrading bacteria (Beaulieu et al. 1983; Moore et al. 1997; Nautiyal et al. 1991; Tremblay et al. 1987), as only a few S. meliloti and Rhizobium leguminosarum bv. viciae strains were found to catabolize this molecule (McSpadden-Gardener and de Bruijn 1998; Rossbach et al. 1995b; Wexler et al. 1995). Furthermore, and in contrast to the agrobacterial opines that might promote a selective advantage for pathogenic agrobacteria, the rhizopine would favor the growth of plant-beneficial bacteria such as rhizobia.

\section{Other growth enhancement strategies.}

The above described biased rhizosphere strategy is not the only way to improve the survival of a plant-associated microbe in the rhizosphere, and alternative modifications of the microbe may contribute to increasing its competitiveness in the plant environment. These modifications could target several aspects of the microbial physiology, including production of secondary metabolites, adaptation to extreme environment, or competition for nonorganic resources. In this respect, engineering iron uptake, i.e., engineering both siderophore production and, more surprisingly, siderophore utilization should stimulate, at least in part, populations of inoculant strains in the rhizosphere (Loper and Buyer 1991; Loper and Henkels 1999; Mirleau et al. 2000). Other approaches are exemplified by the elegant work of Sun and associates (1995), who identified a protein with antifreeze activity in the culture supernatant of a $P$. putida strain isolated from the Canadian arctic region that allows the bacteria to survive at very low temperature $\left(-20\right.$ to $\left.-50^{\circ} \mathrm{C}\right)$. The encoding gene could be transferred to a microbe of agricultural interest to promote its ability to better survive under winter conditions. Additional targets should be considered such as the enzyme 1-aminocyclopropane-1-carboxylic acid deaminase, the presence of which contributes to the PGPR characteristic of the host strain and possibly to its competitiveness under nitrogen limiting conditions ( $\mathrm{Li}$ et al 2000; Shah et al. 1998).

\section{Engineering root exudation as a tool to understand dynamics of microbe colonization in the rhizosphere.}

As said above, plant-microbe interactions in the rhizophere are based in part on complex, trophic relationships. Perturbing these trophic relationships may therefore appear as an interesting tool to study these interactions and eventually to formulate some rules permitting the design of successful biased rhizosphere procedures. Oger and associates (1997) used a similar design to study the impact of a small modification affecting root exudation on the soil microflora. Transgenic Lotus plants producing opines (and their nonproducing counterparts) were installed in microcosms filled with natural, nonsterilized soil. The densities of total, cultivable bacteria were identical whatever the origin of the plants and the date of sampling, as were those of several, easily screenable bacterial groups (such as fluorescent pseudomonads, agrobacteria, thermotolerant, and sporulating bacteria). However, the concentration of naturally occurring opine utilizers in the rhizosphere of opine-producing plants appeared to be 25 to 1000 times higher than that in the rhizosphere of nontransformed plants (Oger et al. 1997). Remarkably, this growth stimulation is approximately 10 to 500 times higher than that reported by other authors in other model systems (Savka and Farrand 1997; Wilson and Lindow 1994; Wilson et al. 1995). This difference may be attributed to the design of the experiments. Wilson and associates (1995) and Savka and associates (1996) essentially investigated the variation of the population density of one given strain, degrading or not degrading opine, in competition with a limited number of strains. This population density indeed depends directly upon the ability of this strain to utilize the novel opine resource. However, in experiments performed in a nonsterile 
environment, the targeted population is wider, encompassing all the bacteria capable of using the opines as a growth substrate. Therefore, their population density will also depend on the presence of competing microorganisms, the population of which may also be affected by the presence of the novel opine resource. The above difference of results may also reflect fundamental differences between the rhizosphere and the phyllosphere. Wilson and associates (1995) observed that the leaves of the transgenic plants producing opines support the growth of a more abundant microbial population, suggesting that the synthesized mannityl opines may represent additional carbon sources for the degrading bacteria. This result, obtained at the leaf surface, contrasts with corresponding results obtained in the rhizosphere (Savka and Farrand 1997). At the root surface, the novel nutritional resource provided by the opineproducing line generally does not appear to influence the overall population density of microbes (Oger et al. 1997, 2000; Savka and Farrand 1997). These density values related to the carrying capacities of both the rhizosphere and the phyllosphere, which are determined by factors that differ from one environment to the other.

The experiment described above also allowed Oger and associates (1997) to set up a model system to study the consequence of the release of genetically-modified plants at the rhizosphere level. The experimental data demonstrate that the interaction between the transgenic plants and the associated bacterial microflora is specific: (i) at the bacterial level since only some bacterial groups are the "target" of one or more modifications allowing the plant to produce opines and (ii) at the transgene level, since the results obtained for one transgene (e.g., the nos gene responsible for nopaline synthesis [NOP]) are not comparable with those obtained for other transgenes (e.g., the mas genes involved in the synthesis of the mannityl opines including mannopine [MOP]). These data were confirmed by further studies on the bacterial populations utilizing either MOP or NOP selected from the rhizosphere of transgenic Lotus plants. Oger and Dessaux (unpublished data) have shown that the populations of bacteria degrading MOP differ noticeably from those degrading NOP. Further studies that involved the replacement of transgenic plants producing opines by their nontransformed, near-isogenic counterparts confirmed these results. They demonstrated that opine production by transgenic plants may lead, in the long run, to the selection of bacterial populations adapted to the rhizosphere that can maintain themselves at high concentrations, even upon removal of the transgenic plants. This feature has also some generic inference in terms of bacterial root colonization, as it strongly suggests that bacterial populations colonizing the root surface might be determined by plant exudates that are no longer produced at the time of the analysis (Oger et al. 2000).

\section{RESEARCH PERSPECTIVES}

The value of the biased rhizosphere procedure, whether it relies on opine or opine-like molecules to specifically promote the growth of a microorganism, should now be evaluated during field trial and involve crops, even minor crops, and microbes of interest. But beyond this technique, it appears that studies on plant-microbe interaction in the rhizosphere-and more generally, microbial ecology in complex environmentsare still limited by our knowledge of the biological diversity characteristic of these environments (Copley 2000; O'Connell et al. 1996). This research field will undoubtedly benefit in the near future from the emergence of high output molecular techniques (Cummings and Relman 2000), such as those based on the analysis of the ribosomal operons and genes (Ranjard et al. 2001; Smalla et al. 2001) or those derived from the data gener- ated by sequencing programs (Galibert et al. 2001). Additionally, further research orientations may be considered. A few of these are discussed below.

\section{Engineering plant-associated microbial populations through signal interference.}

Competition in the rhizosphere and successful colonization of a plant surface depend on multiple functions that often share a common feature; they are regulated. Among the identified regulatory mechanisms, one known as quorum-sensing (QS) has received considerable attention within the last few years. The mechanism of QS is characterized by the synthesis and accumulation in a given environment of low-molecular-weight signal molecules, as a function of the population density of microbes producing these molecules and the rate of diffusion of the molecules in the environment. Once a threshold concentration of the signal molecules-hence, a threshold population density of the microbe-is reached, the signal is perceived and allows the relevant microbes to respond in a concerted way. Several microbial functions are known to be regulated via QS, including biofilm formation, pathogenicity, conjugal transfer of plasmid, swarming ability, and iron uptake, etc. (Fuqua et al. 2001; Miller and Bassler 2001; Parsek and Greenberg 2000; Whitehead et al. 2001). The importance of the regulated functions in terms of microbial fitness and aggressiveness in the plant environment implies that rhizosphere engineering for improved biological control could take into account strategies that aim at "jamming" microbial communication (Rice et al. 1999; Robson et al. 1997). Two terms of an option may be considered: superimposing a signal on the existing one or canceling the signal.

The first approach has been recently addressed by Fray and associates (1999), who generated transgenic plants producing QS signal molecules of the $N$-acyl-homoserine lactone (HSL) class and showed that the HSL signal synthesized by the plants was fully recognized by the HSL-responding bacteria in the plant environment. Similar HSL-producing plants inhibited pathogenicity of $E$. carotovora, possibly by inducing the pathogenic functions of the bacteria too early, i.e., while the bacterial concentration and metabolic activity were sufficient to induce plant defense response but not sufficient to efficiently damage the plant (Mae et al. 2001). The production of multiple classes of HSL signals (long and short chain HSLs) may also contribute to jamming communication among members of the plant-associated bacterial community and may lead to an increase in plant disease resistance (Weil et al. 2001). Consistent with superimposing a signal on another, is the identification and use of natural products from marine systems to interfere with HSL signaling (Kjelleberg et al. 1997). A HSL antagonist identified from an Australian red alga, Delisea pulchra, characterized as a haloganated furanone (Manefield et al. 1999) inhibited biofilm development in Pseudomonas aeruginosa, a trait regulated by QS (Hentzer et al. 2002). Perhaps plants could be engineered to produce one or more analogues of HSLs to function as antagonists to reduce the onset of pathogenic traits in natural pathogens and, in certain plant-bacterial systems, agonists of beneficial traits regulated by QS. The above works, however, support the concept that plant-microbe systems can be engineered to enable plants to directly regulate genes in plant-associated bacteria regulated by QS.

The second approach has also been shown to be valuable. In this case, plants are engineered to produce an enzyme responsible for degradation of the QS signal. Such plants quench the pathogen QS signaling and show an elevated resistance to infection by the pathogen E. carotovora (Dong et al. 2001). Interestingly, degradation of the QS molecule may play a role in signal persistence in complex environments, as bacteria and 
enzymes inhibiting or degrading QS signals (Dong et al. 2000; Leadbetter and Greenberg 2000; Zhang et al. 2002) have been isolated from soil and plant root systems. These results suggest that microbes degrading HSL may also be used as biocontrol agents to alter HSL-regulated functions of other microbes, such as Pseudomonas, Agrobacterium, or Erwinia spp. Preliminary experiments involving various microorganisms engineered to degrade HSL molecules support the use of this new "type" of biocontrol agents (Reimmann et al. 2002). In the above examples, signal interference affected one or more biological functions rather than microbial population densities. However, considering that functions such as antibiotic production or synthesis of antifungal compounds are regulated via QS (Chin-A-Woeng et al. 2001; Wood et al. 1997), it is reasonable to assume that the composition of the plant-associated microflora may be affected at the root system of plants, overproducing HSL molecules or HSL-degrading enzymes.

\section{A question for future research: Could we engineer predation?}

In a complex environment, it is assumed that a population reaches an equilibrium as a result of the multiplication of its members at the expense of the available resources and as a result of the disappearance of its members due to predation. Microorganisms, including bacteria, are no exception to this rule. Engineering predation of bacteria may therefore be a way to influence given microbial populations. To achieve this goal, however, predation has to be directed towards microbes to be controlled; in other words, it has to be specific. Though this may not be regarded as predation sensu stricto, the use of bacteria producing one or more targeted bacteriocins has received some attention (Smidt and Vidaver 1982) and allowed the development of at least one successful biocontrol agent, namely, Agrobacterium sp. strain K84 (Dessaux et al. 1998), specifically active against nopaline-type Agrobacterium tumefaciens strains. Phages have been proposed to be used as active antibacterial agents (Merril et al. 1996). Indeed, in aquatic environments, phages are key determinants of the density of several microbial populations (Suttle et al. 1990). However, though phages are specific for target bacteria, including plant pathogenic bacteria (Eayre et al. 1995), there is limited data on their use and value as biocontrol agents in the field or towards plant-associated bacteria (Ashelford et al. 1999; Leverentz et al. 2001). A successful example of a phage-based strategy deals with the control of the brown blotch disease of cultivated mushroom (Agaricus bisporus) caused by the pathogenic agent Pseudomonas tolaasii. Phages isolated from diseased carpophores were analyzed, and some were found to efficiently lyse isolates of $P$. tolaasii but not related $P$. putida or $P$. fluorescens strains (Guillaumes et al. 1988; Munsch et al. 1991). Biological control efficiency was evident as crop losses were reduced from 80 to $30 \%$ when the growth mixture of the Agaricus fungus contained phage isolated from diseased carpophores. However, some resistance to phage was observed after prolonged treatments (Munsch and Olivier 1995), a factor which may constitute a limitation to the future use of bacteriophages in the field (Bohannan and Lenski 2000).

Bacteria from the genus Bdellovibrio (Guerrero et al. 1986) are other candidates for engineering predation. (A review on the genus Bdellovibrios may also be found on the Springer website listed below.) First isolated as members of plant pathogenic family Pseudomonaceae (Stolp and Petzold 1962), these microbes are characterized by their remarkable ability to feed on other bacteria. These properties could be used within the frame of biological control procedures in spite of our limited knowledge on the mechanisms involved in Bdellovibrio spp. predation. Though a high density of preys might be necessary for Bdellovibrio spp. survival (discussed on web site listed below), these microorganisms have been efficiently used to control plant pathogenic bacteria, including Pseudomonas sp. (Scherff 1973), Erwinia carotovora, and Xanthomonas campestris (Uematsu 1980). These predatory microorganisms may also be deleterious for microbes beneficial to plants, a risk exemplified by the observation that an Azospirillum sp. is a potential host for propagating Bdellovibrio isolates (Germida 1987). The finding that strains of Bdellovibrio exhibit some specificity towards their preys (Jurkevitch et al. 2000) opens, however, new prospects for the future development of predation-based biocontrol agents.

\section{ACKNOWLEDGMENTS}

The authors wish to thank E. Jurkevitch (Rehovot), P. Lemanceau (Dijon), and F. Olivier (Bordeaux) for helpful discussions on predation and biological control and for providing various references to published works. This work was partially supported by a Dean's Summer Research Fellowship (DSRF) and a Project Initiation Grant (PIG) to MAS from the College of Science, Rochester Institute of Technology, Rochester, NY, U.S.A.

\section{LITERATURE CITED}

Adams, P. B. 1990. The potential of mycoparasites for biological control of plant diseases. Annu. Rev. Phytopathol. 28:59-72.

Allison, M. J., Hammond, A. C., and Jones, R. J. 1990. Detection of ruminal bacteria that degrade toxic dihydroxypyridine compounds produced from mimosine. Appl. Environ. Microbiol. 56:590-594

Arrage, A. A., Phelps, T. J., Benoit, R. E., and White, D. C. 1993. Survival of subsurface microorganisms exposed to UV radiation and hydrogen peroxide. Appl. Environ. Microbiol. 59:3545-3550.

Asano, N., Oseki, K., Tomioka, E., Kizu, H., and Matsui, K. 1994. Ncontaining sugars from Morus alba and their glycosidase inhibitory activities. Carbohydr. Res. 259:243-255.

Asano, N., Kato, A., Kizu, H., Matsui, K., Watson, A. A., and Nash, R. J. 1996. Calystegine B4, a novel trehalase inhibitor from Scopolia japonica. Carbohydr. Res. 293:195-204.

Ashelford, K. E., Day, M. J., Bailey, M. J., Lilley, A. K., and Fry, J. C. 1999. In situ population dynamics of bacterial viruses in a terrestrial environment. Appl. Environ. Microbiol. 65:169-174

Beaulieu, C., Coulombe, L. J., Granger, B., Miki, C., Beauchamp, C. Rossignol, R., and Dion, P. (1983) Characterization of opine-utilizing bacteria isolated from Quebec. Phytoprotection 64:61-68.

Bloemberg, G. V., and Lugtenberg, B. J. J. 2001. Molecular basis of plant growth promotion and biocontrol by rhizobacteria. Curr. Opin. Plant Biol. 4:343-350.

Bohannan, B. J. M., and Lenski, R. E. 2000. Linking genetic change to community evolution: insights from studies of bacteria and bacteriophage. Ecol. Lett. 3:362-377.

Bowen, G. D. 1991. Microbial dynamics in the rhizosphere: possible strategies in managing rhizosphere populations. Pages 25-32 in: The Rhizosphere and Plant Growth. D. L. Keister and P. B. Cregan, eds. Kluwer Academic Publishers, Dordrecht, The Netherlands.

Chin-A-Woeng, T. F., van den Broek, D., de Voer, G., van der Drift, K. M., Tuinman, S., Thomas-Oates, J. E., Lugtenberg B. J. J., and Bloemberg, G. V. 2001. Phenazine-1-carboxamide production in the biocontrol strain Pseudomonas chlororaphis PCL1391 is regulated by multiple factors secreted into the growth medium. Mol. Plant-Microbe Interact. 14:969-979.

Colbert, S. F., Isakeit, T., Ferri, M., Weinhold, A. R., Hendson, M., and Schroth, M. N. 1993a. Use of an exotic carbon source to selectively increase metabolic activity and growth of Pseudomonas putida in soil. Appl. Environ. Microbiol. 59:2056-2063.

Colbert, S. F., Schroth, M. N., Weinhold, A. R., and Hendson, M. 1993b. Enhancement of population densities of Pseudomonas putida PpG7 in agricultural ecosystems by selective feeding with the carbon source salicylate. Appl. Environ. Microbiol. 59:2064-2070.

Colbert, S. F., Hendson, M., Ferri, M., and Schroth, M. N. 1993c. Enhanced growth and activity of a biocontrol bacterium genetically engineered to utilize salicylate Appl. Environ. Microbiol 59:2071-2076.

Cook, R. J., Thomashow, L. S., Weller, D. M., Fujimoto, D., Mazzola, M., Bangera, G., and Kim, D. 1995. Molecular mechanisms of defense by rhizobacteria against root disease. Proc. Natl. Acad. Sci. U.S.A. 92:4197-4201.

Copley, J. 2000. Ecology goes underground. Nature 406:452-454. 
Cullen, D., and Andrews, J. H. 1984. Epiphytic microbes as biological control agents. Plant-microbe interactions. Pages 381-399 in: PlantMicrobe Interactions. T. Kosuge and E. W. Nester, eds. McMillan, New York.

Cummings, C. A., and Relman, D. A. 2000. Using DNA microarrays to study host-microbe interactions. Emerg. Infect. Dis. 6:513-525.

Curl, E. A., and Truelove, B. 1986. The rhizosphere. Advanced series in Agricultural Sciences, Vol. 15. B. Yaron, ed. Springer-Verlag, Berlin.

Dessaux, Y., Tempé, J., and Farrand, S. K. 1987. Genetic analysis of mannityl opine catabolism in octopine-type Agrobacterium tumefaciens strain 15955. Mol. Gen. Genet. 208:301-308.

Dessaux, Y., Petit, A., Farrand, S. K., and Murphy, P. J. 1998. Opines and opine-like molecules involved in plant-Rhizobiaceae interactions. Pages 173-197 in: The Rhizobiaceae. H. P. Spaink, A. Kondorosi, and P. J. J Hooykaas, eds. Kluwer Academic Publishers, Dordrecht, The Netherlands.

Devliegher, W., Syamsul Arif, M. A., and Verstraete, W. 1995. Survival and plant growth promotion of detergent-adapted Pseudomonas fluorescens ANP15 and Pseudomonas aeruginosa 7NSK2. Appl. Environ. Microbiol. 61:3865-3871.

Dong, Y. H., Xu, J. L., Li, X. Z., and Zhang, L. H. 2000. AiiA, an enzyme that inactivates the acylhomoserine lactone quorum-sensing signal and attenuates the virulence of Erwinia carotovora. Proc. Natl. Acad. Sci. U.S.A. 97:3526-3531.

Dong, Y. H., Wang, L. H., Xu, J. L., Zhang, H. B., Zhang, X. F., Zhang, L. H. 2001. Quenching quorum-sensing-dependent bacterial infection by an N-acyl homoserine lactonase. Nature 411:748-749.

Eayre, C. G., Bartz, J. A., and Concelmo, D. E. 1995. Bacteriophages of Erwinia carotovora and Erwinia ananas isolated from freshwater lakes. Plant Dis. 79:801-804.

Farrand, S. K., Wilson, M., Lindow, S. E., and Savka, M. A. 1994a. Modulating competition in the rhizosphere by resource utilization. Abstr. Mol. Ecol. 3:619.

Farrand, S. K., Wilson, M., Lindow, S. E., and Savka, M. A. 1994b. Modulating colonization by plant-associated microbes. Pages 233-237 in: Improving Plant Productivity with Rhizosphere Bacteria. M. H Ryder, R. P. Stephens, and G. D. Bowen, eds. CSIRO, Glen Osmond, Australia.

Fox, P. M., and Borthakur, D. 2001. Selection of several classes of mimosine-degradation-defective $\mathrm{Tn} 3 \mathrm{HoHo}$ gus-insertion mutants of Rhizobium sp. strain TAL1145 on the basis of mimosine-inducible GUS activity. Can. J. Microbiol. 47:488-494.

Fray, R. G., Throup, J. P., Daykin, M., Wallace, A., Williams, P., Stewart, G. S., and Grierson, D. 1999. Plants genetically modified to produce $\mathrm{N}$-acylhomoserine lactones communicate with bacteria. Nature/Biotechnol. 17:1017-1020.

Fuqua, C., Parsek, M. R., and Greenberg, E. P. 2001. Regulation of gene expression by cell-to-cell communication: Acyl-homoserine lactone quorum sensing. Annu. Rev. Genet. 35:439-468

Galibert, F., Finan, T. M., Long, S. R., Puehler, A., Abola, P., Ampe, F. Barloy-Hubler, F., Barnett, M. J., Becker, A., Boistard, P., Bothe, G., Boutry, M., Bowser, L., Buhrmester, J., Cadieu, E., Capela, D., Chain, P., Cowie, A., Davis, R. W., Dreano, S., Federspiel, N. A., Fisher, R. F., Gloux, S., Godrie, T., Goffeau, A., Golding, B., Gouzy, J., Gurjal, M., Hernandez-Lucas, I., Hong, A., Huizar, L., Hyman, R. W., Jones, T., Kahn, D., Kahn, M. L., Kalman, S., Keating, D. H., Kiss, E., Komp, C., Lelaure, V., Masuy, D., Palm, C., Peck, M. C., Pohl, T. M., Portetelle, D., Purnelle, B., Ramsperger, U., Surzycki, R., Thebault, P., Vandenbol, M., Vorhoelter, F. J., Weidner, S., Wells, D. H., Wong, K., Yeh, K.-C., and Batut, J. 2001. The composite genome of the legume symbiont Sinorhizobium meliloti. Science 293:668-672.

Germida, J. J. 1987 Isolation of Bdellovibrio spp. that prey on Azospirillum brasilense in soil. Can. J. Microbiol. 33:459-461

Gordon, D. M., Ryder, M. H., Heinrich, K., and Murphy, P. J. 1996. An experimental test of the rhizopine concept in Rhizobium meliloti. Appl. Environ. Microbiol. 62:3991-3996.

Grayer, R. J., and Kokubun, T. 2001. Plant-fungal interactions: The search for phytoalexins and other antifungal compounds from higher plants. Phytochemistry 56:253-63.

Grayston, S. J., Wang, S., Campbell, C. D., and Edwards, A. C. 1998. Selective influence of plant species on microbial diversity in the rhizosphere. Soil Biol. Biochem. 30:369-378.

Guerrero, R., Pedros-Alio, C., Esteve, I., Mas, J., Chase, D., and Margulis, L. 1986. Predatory prokaryotes: Predation and primary consumption evolved in bacteria. Proc. Natl. Acad. Sci. U.S.A. 83:21382142 .

Guillaumes, J., Houdeau, G., Germain, R., and Olivier J. M. 1988. Amélioration de la lutte biologique contre Pseudomonas tolaasii par utilisation de bacteriophages asociés à une bactérie antagoniste. EPPO Bull. 18:77-82.
Guyon, P., Petit, A., Tempé, J., and Dessaux, Y. 1993. Transformed plants producing opine specifically promote the growth of opine-degrading Agrobacteria. Mol. Plant-Microbe Interact. 6:92-98.

Hammond, A. C. 1995. Leucaena toxicosis and its control in ruminants. J. Anim. Sci. 73:1487-1492

Hammond, A. C., Allison, M. J., Williams, M. J., Prine, G. M., and Bates, D. B. 1989. Prevention of leucaena toxicosis of cattle in Florida by ruminal inoculation with 3-hydroxy-4-(1H)-pyridone-degrading bacteria. Am. J. Vet. Res. 50:2176-2180.

Heinrich, K., Gordon, D. M., Ryder, M. H., and Murphy, P. J. 1999. A rhizopine strain of Sinorhizobium meliloti remains at a competitive nodulation advantage after an extended period in the soil. Soil Biol. Biochem. 31:1063-1065.

Hentzer, M., Riedel, K., Rasmussen, T. B., Heydorn, A., Anderson, J. B., Parsek, M. R., Rice, S. A., Eberl, L., Molin, S., Hoiby, N., Kjelleberg, S., and Givskov, M. 2002. Inhibition of quorum sensing in Pseudomonas aeruginosa biofilm bacteria by a halogenated furanone compound Microbiol. 148:87-102.

Holmes, J. H., Humphrey J. D., Walton, E. A., and O'Shea, J. D. 1981. Cataracts, goitre and infertility in cattle grazed on an exclusive diet of Leucaena leucocephala. Aust. Vet. J. 57:257-261.

Howe, T. G., and Ward, J. M. 1976. The utilization of tween 80 as carbon source by Pseudomonas. J. Gen. Microbiol. 92:234-235.

Jones, R. J., and Megarrity, R. G. 1986. Successful transfer of DHP-degrading bacteria from Hawaiian goats to Australian ruminants to overcome the toxicity of Leucaena. Aust. Vet. J. 63:259-262.

Jurkevitch, E., Minz, D., Ramati, B., and Barel, G. 2000. Prey range characterization, ribotyping, and diversity of soil and rhizosphere Bdellovibrio spp. on phytopathogenic bacteria. Appl. Environ. Microbiol. 66:2365-2371.

Kjelleberg, S., Steinberg, P., Givskov, M., Gram, L., Manefield, M., and de Nys, R. 1997. Do marine natural products interfere with prokaryotic AHL regulatory systems? Aquat. Microb. Ecol. 13:85-93.

Kloepper, J. W., and Schroth, M. N. 1978. Plant growth promoting rhizobacteria. Pages GG-GG in: Proceedings of the 4th International Conference on Plant Pathogneic Bacteria, Angers. M. Ridé, ed. Editions INRA, Angers, France.

Kloepper, J. W., Leong, J., Teintze, M., and Schroth, M. N. 1978. Pseudomonas siderophores: a mechanism explaining disease-suppressive soils. Curr. Microbiol. 4:317-320.

Kulkarni, S., and Nautiyal, C. S. 2000. Effects of salt and pH stress on temperature-tolerant Rhizobium sp. NBRI330 nodulating Prosopis juliflora. Curr. Microbiol. 40:221-226.

Lajoie, C. A., Chen, S.-Y., Oh, K.-C., and Strom, P. F. 1992. Development and used of field application vectors to express nonadaptative foreign genes in competitive environments. Appl. Environ. Microbiol. 58:655663.

Lam, S. T., and Gaffney, T. D. 1993. Biological activities of bacteria used in pathogen control. Pages 291-390 in: Biotechnology in Plant Disease Control. I. Chet, ed. Wiley-Liss, New York.

Lam, S. T., Torkewitz, N. R., Nautiyal, C. S., and Dion, P. 1991. Impact of the ability to utilize a single substrate on colonization competitiveness. Phytopathology 81:1163-1164.

Leadbetter, J. R., and Greenberg, E. P. 2000. Metabolism of acyl-homoserine lactone quorum-sensing signals by Variovorax paradoxus. J. Bacteriol 182:6921-6926.

Lemanceau P., Bakker, P. A. H. M., De Kogel, W. J., Alabouvette, C., and Schippers, B. 1992. Effect of pseudobactin 358 production by Pseudomonas putida WCS358 on suppression of fusarium wilt of carnations by nonpathogenic Fusarium oxysporum Fo47. Appl. Environ. Microbiol. 58:2978-2982

Lemanceau, P., Corberand, T., Gardan, L., Latour, X., Laguerre, G., Boeufgras, J.-M., and Alabouvette, C. 1995. Effect of two plant species, Flax (Linum usitatissinum L.) and Tomato (Lycopersicum esculentum Mill.), on the diversity of soilborne populations of fluorescent pseudomonads. Appl. Environ. Microbiol. 61:1004-1012

Leverentz, B., Conway, W. S., Alavidze, Z., Janisiewicz, W. J., Fuchs, Y., Camp, M. J., Chighladze, E., Sulakvelidze, A. 2001. Examination of bacteriophage as a biocontrol method for salmonella on fresh-cut fruit: A model study. J. Food Prot. 64:1116-1121.

Li, J., Ovakim, D. H., Charles, T. C., and Glick, B. R. 2000. An ACC deaminase minus mutant of Enterobacter cloacae UW4 no longer promotes root elongation. Curr. Microbiol. 41:101-105.

Loper, J. E., and Buyer, J. S. 1991. Siderophores in microbial interactions on plant surfaces. Mol. Plant-Microbe Interact. 4:5-13.

Loper, J. E., and Henkels, M. D. 1999. Utilization of heterologous siderophores enhances levels of iron available to Pseudomonas putida in rhizosphere. Appl. Environ. Microbiol. 65:5357-5363.

Mäe, A., Montesano, M., Koiv, V., and Palva, E. T. 2001. Transgenic plants producing the bacterial pheromone $N$-acyl-homoserine lactone 
exhibit enhanced resistance to the bacterial phytopathogen Erwinia carotovora. Mol. Plant-Microbe Interact. 14:1035-1042.

Mansouri, H., Petit, A., and Dessaux, Y. 2002. Engineered rhizosphere: the trophic bias generated by opine-producing plants is independent of the opine-type, the soil origin and the plant species. Appl. Environ. Microbiol. 68:2562-2566.

Manefield, M., de Nyl, R., Kumar, N., Read, R., Givskov, M., Steinberg, P., Kjelleberg, S. 1999. Evidence that halogenated furanones from Delisea pulchra inhibit acylated homoserine lactone (AHL)- mediated gene expression by displacing the AHL signal from its receptor protein. Microbol. 145:283-291.

Mazzola, M., Cook, R. J., Thomashow, L. S., Weller, D. M., and Pierson, L. S., III. 1992. Contribution of phenazine antibiotic biosynthesis to the ecological competence of fluorescent pseudomonads in soil habitats. Appl. Environ. Microbiol. 58:2616-2624.

McSpadden-Gardener, B. B. 1998. Assessing the potential of creating biased rhizospheres based on inositol rhizopines. Ph.D. Dissertation, Michigan State University, East Lansing, MI.

McSpadden-Gardener B. B., and de Bruijn F. J. 1998. Detection and isolation of novel rhizospine-catabolizing bacteria from the environment. Appl. Environ. Microbiol. 64:4944-4949.

Merril, C. R., Biswas, B., Carlton, R., Jensen, N. C., Creed, G. J., Zullo, S., and Adhya, S. 1996. Long-circulating bacteriophage as antibacterial agents. Proc. Natl. Acad. Sci. U.S.A. 93:3188-3192.

Miethling, R., Wieland, G., Backhaus, H., and Tebbe, C. C. 2000. Variation of microbial rhizosphere communities in response to crop species, soil origin, and inoculation with Sinorhizobium meliloti L33. Microb. Ecol. 40:43-56.

Miller, M. B., and Bassler, B. L. 2001. Quorum sensing in bacteria. Annu. Rev. Microbiol. 55:165-199.

Mirleau, P., Delorme, S., Philippot, L., Meyer, J.-M., Mazurier, S., and Lemanceau P. 2000. Fitness in soil and rhizosphere of Pseudomonas fluorescens C7R12 compared with a C7R12 mutant affected in pyoverdine synthesis and uptake. FEMS (Fed. Eur. Microbiol. Soc.) Microbiol. Ecol. 34:35-44.

Molyneux, R. J., Pan, Y. T., Goldmann, A., Tepfer, D. A., and Elbein, A. D. 1993. Calystegins, a novel class of alkaloid glycosidase inhibitors. Arch. Biochem. Biophys. 304:81-88.

Moore, L. W., Chilton, W. S., and Canfield, M. L. 1997. Diversity of opines and opine-catabolizing bacteria isolated from naturally occurring crown gall tumors. Appl. Environ. Microbiol. 63:201-207.

Munsch, P., and Olivier, J. M. 1995. Biocontrol of bacterial blotch of the cultivated mushroom with lytic pahges: Some practical considerations. Pages 595-602 in: Science and Cultivation of Edible Fungi. T. J. Elliott, ed. A. A. Balkema, Rotterdam, The Netherlands.

Munsch, P., Olivier, J. M., and Houdeau, G. 1991. Experimental control of bacterial blotch by bacteriophages. Pages 389-396 in: Science and Cultivation of Edible Fungi. M. J. Maher, ed. A. A. Balkema, Rotterdam, The Netherlands.

Murphy, P. J., Heycke, N., Banfalvi, Z., Tate, M. E., de Bruijn, F. J., Kondorosi, A., Tempé, J., and Schell, J. 1987. Genes for the catabolism and synthesis of an opine-like compound in Rhizobium meliloti are closely linked and on the Sym plasmid. Proc. Natl. Acad. Sci. U.S.A. 84:493-497.

Murphy, P. J., Trenz S. P., Grzemski W., de Bruijn F. J., and Schell, J. 1993. The Rhizobium meliloti rhizopine mos locus is a mosaic structure facilitating its symbiotic regulation. J. Bacteriol. 175:5193-5204.

Naseby, D. C., and Lynch, J. M. 1999. Effects of Pseudomonas fluorescens F113 on ecological functions in the pea rhizosphere are dependent on pH. Microb. Ecol. 37:248-256.

Nautiyal, C. S., Dion, P., and Chilton, W. S. 1991. Mannopine and mannopinic acid as substrates for Arthrobacter sp. strain MBA209 and Pseudomonas putida NA513. J. Bacteriol. 173:2833-2841.

O’Connell, K. P., Goodman, R. M., and Handelsman, J. 1996. Engineering the rhizosphere: Expressing a bias. Trends Biotechnol. 14:83-88

Oger, P., Petit, A., and Dessaux, Y. 1997. Genetically engineered plants producing opines alter their biological environment. Nature/Biotechnol. 15:369-372.

Oger, P., Mansouri, H., and Dessaux, Y. 2000. Effect of crop rotation and soil cover on alteration of the soil microflora generated by the culture of transgenic plants producing opines. Mol. Ecol. 9:881-890.

O'Sullivan, D. J., and O'Gara, F. 1992. Traits of fluorescent Pseudomonas spp. involved in suppression of plant pathogens. Microbiol. Rev. 56:662-676

Parke, J. L. 1991. Root colonization by indigenous and introduced microorganisms. Pages 33-42, in: The Rhizosphere and Plant Growth. D. L. Keister and P. B. Cregan, eds. Kluwer Academic Publishers, Dordrecht, The Netherlands.

Parsek, M. R., and Greenberg, E. P. 2000. Acyl-homoserine lactone quorum sensing in gram-negative bacteria: A signaling mechanism in- volved in associations with higher organisms. Proc. Natl. Acad. Sci. U.S.A. 97:8789-8793.

Picard, C., Di Cello, F., Ventura, M., Fani, R., and Guckert, A. 2000. Frequency and biodiversity of 2,4-diacetylphloroglucinol-producing bacteria isolated from the maize rhizosphere at different stages of plant growth. Appl. Environ. Microbiol. 66:948-955.

Ranjard, L., Poly, F., Lata, J.-C., Mougel, C., Thioulouse, J., and Nazaret, S. 2001. Characterization of bacterial and fungal soil communities by automated ribosomal intergenic spacer analysis fingerprints: Biological and methodological variability. Appl. Environ. Microbiol. 67:4479-4487.

Reimmann, C., Ginet, N., Michel, L., Keel, C., Michaux, P., Krishnapillai, V., Zala, M., Heurlier, K., Triandafillu, K., Harms, H., Defago, G., and Haas, D. 2002. Genetically programmed autoinducer destruction reduces virulence gene expression and swarming motility in Pseudomonas aeruginosa PAO1. Microbiology 148:923-932

Rengel, Z., Ross, G., and Hirsch, P. 1998. Plant genotype and micronutrients status influence colonization of wheat roots by soil bacteria. J. Plant Nutr. 21:99-113.

Rice, S. A., Givskov, M., Steinberg, P., Kjelleberg, S. 1999. Bacterial signals and antagonists: the interaction between bacteria and higher organisms. J. Mol. Microbiol. Biotechnol. 1:23-31

Robson, N. D., Cox, A. R., McGowan, S. J., Bycroft, B. W., and Salmond, G. P. C. 1997. Bacterial N-acyl-homoserine lactone-dependent signalling and its potential biotechnological applications. Trends Biotechnol. 15:458-464.

Rossbach, S., Kulpa, D. A., Rossbach, U., and de Bruijn, F. J. 1994a. Molecular and genetic characterization of the rhizopine catabolism (mocABCR) genes of Rhizobium meliloti L5-30. Mol. Gen. Genet. 245:11-24.

Rossbach, S., McSpadden, B., Kulpa, D., and de Bruijn, F. J. 1994b. Rhizopine synthesis and catabolism genes for the creation of "biased rhizospheres" and a marker system to detect (genetically modified) microorganisms in the soil. Pages 223-244 in: Biotechnology Risk Assessment. M. Levin, C. Grim, and J. S. Angle, eds. University of Maryland Biotechnology Institute, College Park, MD, U.S.A.

Rossbach, S., McSpadden, B., Kulpa, D., Rasul, G., Ganoof, M., and de Bruijn, F. J. 1994c. Use of rhizopine synthesis and catabolism genes to monitor soil bacteria and to create biased rhizospheres. Mol. Ecol. 3:610-611.

Rossbach, S., McSpadden, B., Ganoff, M., and de Bruijn, F. J. 1995a Rhizobium meliloti rhizopine catabolism genes: Distribution, role in competition and potential as marker gene to track microbes. Pages 180-188 in: Biotechnology Risk Assessment. M. Levin and J. S Angle, eds. University of Maryland Biotechnology Institute, College Park, MD, U.S.A.

Rossbach, S., Rasul, G., Schneider, M., Eardly, B., and de Bruijn, F. J. 1995b. Structural and functional conservation of the rhizopine catabolism ( $m o c$ ) locus is limited to selected Rhizobium meliloti strains and unrelated to their geographical origin. Mol. Plant-Microbe Interact. 8:549-559.

Rovira, A. D. 1965a. Plant root exudates and their influence upon soil microorganisms. Pages 170-186 in: Ecology of Soil-Borne Plant Pathogens. K. F. Baker and W. C. Snyder, eds. University of California Press, Berkeley, U.S.A.

Rovira, A. D. 1965b. Interactions between plant roots and soil microorganisms. Annu. Rev. Microbiol. 19:241-266.

Rovira, A. D. 1991. Rhizosphere research: 85 years of progress and frustration. Pages 3-13 in: The Rhizosphere and Plant Growth. D. L. Keister and P. B. Cregan, eds. Kluwer Academic Publishers, Dordrecht, The Netherlands.

Savka, M. A. 1993. Validity of the opine concept in plant-bacterial interactions. Ph.D. dissertation. University of Illinois at UrbanaChampaign, IL.

Savka, M. A., and Binns A. N., 2000. Introduction of DNA into plants. Pages 159-192 in: Gene Transfer Methods: Introduction of Genes into Living Cells and Organisms. P. A. Norton, and L. F. Steel (eds.) Eaton Publishing, Natick, MA, U.S.A.

Savka, M. A., and Farrand S. K. 1992. Mannityl opine accumulation and exudation by transgenic tobacco. Plant Physiol. 98:784-789.

Savka, M. A., and Farrand, S. K. 1997. Modification of rhizobacterial populations by engineering bacterium utilization of a novel plant-produced resource. Nature/Biotechnol. 15:363-368.

Savka, M. A., Black, R. C., Binns, A. N., and Farrand, S. K. 1996. Translocation and exudation of tumor metabolites in crown gall tumors. Mol. Plant-Microbe Interact. 9:310-313.

Schippers, B., Bakker, A. W., and Bakker, P. A. H. M. 1987. Interactions of deleterious and beneficial rhizosphere microorganisms and the effect on cropping practices. Ann. Rev. Phytopathol. 25:339-358.

Siciliano, S. D., Theoret, C. M, de Freitas, J. R., Hucl, P. J., and Germida, 
J. J. 1998. Differences in the microbial communities associated with the roots of different cultivars of canola and wheat. Can. J. Microbiol. 44:844-851.

Scherff, R. H. 1973. Control of bacterial blight of soybean by Bdellovibrio bacteriovorus. Phytopathology. 63:400-402

Shah S., Li J., Moffatt B. A., and Glick, B. R. 1998. Isolation and characterization of ACC deaminase genes from two different plant growthpromoting rhizobacteria. Can. J. Microbiol. 44:833-843.

Smalla, K., Wieland, G., Buchner, A., Zock, A., Parzy, J., Kaiser, S., Roskot, N., Heuer, H., and Berg, G. 2001. Bulk and rhizosphere soil bacterial communities studied by denaturing gradient gel electrophoresis: Plant-dependent enrichment and seasonal shifts revealed. Appl. Environ. Microbiol. 67:4742-4751.

Smidt, M. L., and Vidaver, A. K. 1982. Bacteriocin production by Pseudomonas syringae PsW-1 in plant tissue. Can. J. Microbiol. 28:600-604.

Soedarjo, M., and Borthakur, D. 1996. Mimosine produced by the treelegume Leucaena provides growth advantages to some Rhizobium strains that utilize it as a source of carbon and nitrogen. Plant and Soil 186:87-92.

Soedarjo, M., and Borthakur, D. 1998. Mimosine, a toxin produced by the tree-legume Leucaena provides a nodulation competition advantage to mimosine-degrading Rhizobium strains. Soil Biol. Biochem. 30:1605-1613.

Stolp, H., and Petzold, H. 1962. Untersuchungenuber einen obligat parasitischen mikroorganismus mit lytischer aktivat fur Pseudomonas-bakterien. Phytopatho. Zeit. 45:364-390.

Stutz, E. W., Défago, G., and Kern, H. 1986. Naturally occurring fluorescent pseudomonads involved in suppression of black rot of tobacco. Phytopathology 76:181-185.

Sun, X., Griffith, M., Pasternak, J. J., Glick, B. R. 1995. Low temperature growth, freezing survival, and production of antifreeze protein by the plant growth promoting rhizobacterium Pseudomonas putida GR12-2. Can. J. Microbiol. 41:776-784.

Suttle, C. A., Chan, A. M., and Cottrell, M. T. 1990. Infection of phytoplankton by viruses and reduction of primary productivity. Nature 347:467-469.

Tate, M. E., Ellis, J. G., Kerr, A., Tempé, J., Murrary, K. E., and Shaw, K J. 1982. Agropine: A revised structure. Carbohydr. Res. 104:105-120.

Tempé, J., Petit, A., and Bannerot, H. 1982. Présence de substances semblables à des opines dans des nodosites de luzerne. C.R. Acad. Sc. Paris Serie III. 295:413-426.

Tepfer, D., Goldmann, A., Pamboukdjian, N., Maille, M., Lepingle, A., Chevalier, D., Denarié, J., and Rosenberg, C. 1988. A plasmid of Rhizobium meliloti 41 encodes catabolism of two compounds from root exudate of Calystegium sepium. J. Bacteriol. 170:1153-1161.

Thomashow, L. S., and Weller, D. M. 1988. Role of a phenazine antibi- otic from Pseudomonas fluorescens in biological control of Gaeumannomyces graminis var. tritici. J. Bacteriol. 170:3499-508.

Tremblay, G., Gagliardo, R., Chilton, M.-D., and Dion, P. 1987. Diversity among opine-utilizing bacteria: identification of coryneform isolates. Appl. Environ. Microbiol. 53:1519-1524.

Uematsu, T. 1980. Ecology of Bdellovibrio parasitic to rice bacterial leaf blight pathogen, Xanthomonas oryzae. Rev. Plant Protec. Res. 13:12-26.

Van Loon, L. C., Bakker, P. A. H. M., and Pieterse, C. M. J. 1998. Systemic resistance induced by rhizosphere bacteria. Ann. Rev. Phytopathology 36:453-483.

Weil, J., Fray, R. G., Beck von Bodman, S., and Savka M. A. 2001. Multiple bacterial quorum-sensing signals produced by transgenic plants. Page 169 in: Plant Physiology Abstract Supplement, abstr. 830.

Westover, K. M, Kennedy, A. C, and Kelly, S. E. 1997. Patterns of rhizosphere microbial community structure associated with co-occuring plant species. J. Ecol. 85:863-873.

Wexler, M., Gordon, D. M., and Murphy, P. J. 1995. The distribution of inositol rhizopine genes in Rhizobium populations. Soil Biol. Biochem. 27: 531-537.

Whipps, J. M., and Lynch, J. M. 1985. Energy losses by the plant in rhizodeposition. Ann. Proc. Phytochem. Soc. Eur. 26:59-71.

Whitehead, N. A., Barnard, A. M. L., Slater, H., Simpson, N. J. L., and Salmond, G. P. C. 2001. Quorum-sensing in gram-negative bacteria. FEMS (Fed. Eur. Microbiol. Soc.) Microbiol. Rev. 25:365-404.

Wilson, M., and Lindow, S. E. 1994. Coexistence among epiphytic bacterial populations mediated through nutritional resource partitioning. Appl. Environ. Microbiol. 60:4468-4477.

Wilson, M., Savka, M. A., Hwang, I., Farrand, S. K., and Lindow, S. E. 1995. Altered epiphytic colonization of mannityl opine-producing transgenic tobacco plants by a mannityl opine-catabolizing strain of Pseudomonas syringae. Appl. Environ. Microbiol. 61:2151-2158.

Wood, D. W., Gong, F., Daykin, M. M., Williams, P., and Pierson, L. S., III. 1997. N-acyl-homoserine lactone-mediated regulation of phenazine gene expression by Pseudomonas aureofaciens 30-84 in the wheat rhizosphere. J. Bacteriol. 179:7663-7670.

Zhang, H. B., Wang, L. H., and Zhang, L. H. 2002. Genetic control of quorum-sensing signal turnover in Agrobacterium tumefaciens. Proc. Natl. Acad. Sci. U.S.A. 99:4638-4643.

Zupan, J. R., Muth, T. R., Draper, O., and Zambryski, P. C. 2000. The transfer of DNA from Agrobacterium tumefaciens into plants: A feast of fundamental insights. Plant J. 23:11-28.

\section{AUTHOR-RECOMMENDED INTERNET RESOURCE}

Springer Science Online, The Prokaryotes page: http://link.springer-ny. com/link/service/books/10125/ 